\title{
Marketing Strategies in Rural India - Lessons for Asian Nations
}

\author{
Sandhir Sharma \\ Dept. of Business Management, Punjab College of Technical Education, \\ Punjab, India
}

\begin{abstract}
:
$A$ vast majority of India lives in villages. With the change in the size of demand of products, based on the geographical factors, the corporate circle of India has been compelled to give their attention to the markets in the rural India. The markets which were hitherto, ignored and untapped by the corporate world, gained prominence because of the simple reason of its vast potentiality and the run away success of certain consumer goods which were targeted to the consumers in the urban markets for several decades. Much confusion has been associated, in fact with the word rural as there is no accepted definition for the term and the perceptions of many do for significantly. For some, rural means the places with less than one lakh population. National Council of Applied Economic Research (NCAER) considered income as a basis to establish the rural segment. It has taken the groups with income levels of less than Rs. 11,000 per annum as representatives of rural segments. To some, it is smaller towns and areas having population of less than 10,000 persons. Likewise, the definitions of rural markets vary from company to company. This confusion leads to distorted understanding of the problems of rural marketing, poor diagnosis and more often than not poor prescription. The paper contributes the different perspectives and ideas containing various marketing strategies for the corporates planning to enter into the rural markets.
\end{abstract}

\section{INTRODUCTION}

In India, the size of the rural market is quite significant as it stands at about 75 per cent of the total population as per the 1991 census. The flow of goods and services in these markets can be classified into three categories:

1. Rural to Rural- (the goods and services produced in rural areas and also being consumed/used by the rural people).

2. Rural to Urban-the marketable surplus of the products of the rural areas that are flown to urban markets.

3. Urban to Rural-the flow of goods and services produced in urban areas to rural areas.

The first two types of flows are quite common and has been significant for a very long period. The third type of flow assumed importance in the recent past. The rural market for packaged consumer products has grown nearly three fold, from Rs. 733 crores to Rs. 2,083 crores during 1984 to 1989 [1]. The contribution of rural sales to the all India total has grown substantially from 28 per cent in 1984 to 37 percent in 1989 . While the urban consumer bought barely 1.3 per cent more of toilet soaps each year, his rural counterpart galloped ahead at 15 per cent. In the same period, rural washing powder demand grew 20 per cent a year while urbanites notched up a nearly 5 per cent rise. And for dry cells and razor blades, the rural market showed a small 5 per cent growth annually, while there was a decline in urban areas.

The rural market has achieved a rapid pace of materials prosperity during the last decade due to the improvement in the productivity and outputs of agriculture. There has been a large flow of investment for rural development through many programmes like the Jawahar Rojgar Yojana, 20 point programmes, and programmes under Integrated Rural Development Programme (IRDP), etc. As a result, a large portion of population has moved on to agrarian prosperity levels. The much improved communication and transportation facilities during the recent years, on the one hand, and the rapid rise in the cost of living in the urban areas on the other hand, led to the reverse flow of middle income classes' employees from urban to semi-urban and rural areas for residential purpose. Consequently, products like washing and cleaning material, food and beverages, cosmetics, toiletries, televisions, refrigerators, fans and other appliances, and ready made garments, etc., could penetrate the market to gain substantial market expansion.

Survey report of NCAER provides that the rural household is prosperous enough today to acquire consumer durables such as TV sets, mopeds and pressure cookers. Rural purchases of black and white TV sets (as percentage of total purchases) increased from 26 per cent in 1986 to 31 per cent in 1988, while rural colour TV purchases rose from 11 per cent to 18 per cent in the same period. Electrical appliances (other than TV sets) like irons, mixers, fans and water heaters are now increasingly penetrating the smaller towns and several other areas. The electrification of 60 per cent of the country's villages has further enhanced this upsurge in demand.

\section{MARKETING STRATEGIES}

To develop a suitable marketing strategy to win the rural world, one must have the knowledge about the characteristics of the rural markets. The production driven marketing strategies cannot hold for a longer period due to the greater increase in exposure, fast changing expenditure pattern, buying habits, selectivity and more particularly the health care consciousness of the rural buyer. Therefore, marketing organizations should depend upon either market driven strategies or market driving strategies. Since greater efforts are put in creating the primary demand for goods and services in the rural markets, either of the two 
strategies offer good results; which one of the two depends upon the abilities and strengths of the particular organization. Market driving strategies require greater amount of skilful efforts than the former since such strategy aims at shaping the existing and potential demand in tune with the offerings of the marketing organization. This involves offering such a new product that either makes the buyers to identify new needs or to find a better product to match their existing needs.

A decision on marketing strategy will be followed generally by deciding the marketing programme that will be suitable for the achievement of desired objectives. The most accepted marketing programme with a flexibility to adapt to any strategic purpose is the marketing mix. The marketing mix consists of four major components such as product, price, distribution and promotion. The marketing mix approach helps any organization to find a perfect match among product to form its price, the required accessibility of the product to the target market and the level of communication that is required to stimulate the market demand.

\section{Product}

Product is a very important component of product mix. Product includes goods, services, organizations, places, persons and ideas. A product need not be a mere tangible good and many a time it is a mix of both tangible and intangible attributes. Finalizing a product form to serve the particular needs of the target market is a critical job that requires a lot of research innovative, drive and risk taking abilities in selecting and designing a product. The marketing organization should take into consideration the suitability and adaptability of the product to the target market. Only a few products can have universal adaptability. In many cases different types of products are demanded in different places to satisfy a particular need.

In India, a host of packaged goods, particularly in the categories of cleaning materials, toiletries, cosmetics, food beverages and OTC products could secure a prominent place in the rural markets. The NCAER finds in a survey that for every 1000 rural households, 188 own portable radios, 32 own bicycles and a similar number mechanical wristwatches. The survey also reveals that out of 1000 rural households 970 buy washing cakes, 854 toilet soaps, 617 hair oil cream, 475 casual foot wear, 391 washing powder, 373 electric bulb, 322 vanaspati, and 319 talcum powder. The results show that rural spending on cleanliness, cosmetics and entertainments is increasing. The survey further reveals that the poor segment of India's population (monthly income below Rs. 750) accounts for 60 per cent of the consumption of cold remedies, 66 per cent razor blades and biscuits, 68 percent on tooth paste, 70 per cent on coffee powder and vanaspati, 71 per cent on tea and toilet soaps, 72 per cent on washing cakes and a whopping, 74 percent of total consumption on foot wear and edible oils.
There is even a surge in the demand for personal care products (talcs, shampoos, hair-oil, face creams, toilet soaps) that is directly attributable to the emergence of the 'rural women', as a consumer in her own right. At a recent seminar conducted in Mumbai that drew attention to the 'emerging markets in India', the growth rate of personal care products among women in rural areas was pegged at 50 per cent in the past five years. Sanitary napkins, an entirely novel product introduction, have shown a massive 78 per cent growth rate followed by nail enamel (33 per cent), face creams and shampoos. There are more literate women in rural areas (40 million) than in the urban area (36 million), and the gap is growing every year.

In such a scenario, a good number of companies entered the rural markets with a band of their established products. But after a short filtration most of them realized that rural marketing is not an easy game. The results were mixed. Some products could expand the market, some products could get back from decline to maturity stage in their life cycles and some other products failed to make inroads into the rural market. The reasons are a plenty for such mixed results, one among them is inappropriate product strategy. The companies basically tried to extend their existing select products which were designed to suit the wants and needs of the urban consumers. No significant efforts were made to understand the needs, wants and behavior of the rural buyer that are quite different from that of urban buyer. A more change in the size of the product may not be enough totally. It is necessary therefore, to apply different product concepts between urban and rural markets. Another significant feature is that the rural consumer is a very strong brand loyalist, though it takes time to be really convinced about a particular brand. This characteristic is a positive sign to the sellers to have a continued and guaranteed market for their products if they could penetrate the markets.

\section{Pricing}

Pricing the products for rural markets is a very crucial factor. Price plays a pivotal role in shaping the demand for a product in the rural areas than in the urban. The urban buyers, either due to their economic worthiness or accessibility of a good number of standardized products or for other reasons give more weightage to the 'non-price' factors in the case of a large number of consumer goods. The income and the purchasing power of the rural buyer are very thin to absorb non-price influences. His concern therefore, is to have the product at a price that can be affordable. The demand for most of the products is highly price sensitive. Hence, pricing plays a crucial role in achieving acceptability and preference of the product. It can also be used as a major element in the promotional strategy. To arrive at a pricing decision, the marketers should consider aspects like affordability of the target market, expenses of the buyer on used substitute, prices of the competitors, etc. In order to promote markets for cosmetics in the rural markets the Government of India has considered price as a very important determinant of 
demand. In 1994-95 budget, the Union Government has reduced excise duty on all cosmetics. This step is a motivating factor to the business organizations to have greater penetration into the rural markets.

\section{Distribution}

Distribution system has a vital influence on the business results of any concern. It stands as one of the measures of the marketing strengths. The companies with wide distribution network will find it easy to introduce new products, to take up aggressive sales promotion campaign and to counter the strategies of their competitors. Most business concerns have a very good distribution system to serve the urban markets in India as there are little problems of infrastructural facilities, sizeable groups of buyers and the availability of well established, experienced and motivated middlemen. The situation is just opposite in the case of rural markets. The markets are widely spread and consist of villages covering several thousands of square kilometers. The population is heterogeneous with varied languages, culture and taboos, occupation, income distribution, expenditure pattern, literacy levels and so on. Developing a distribution net work to such markets is really a Herculean task to any organization.

The following are the major characteristics of the rural markets in India:

(a) The markets are widely spread in long distances.

(b) Most buyers are below the poverty line and even the remaining have very limited surplus to buy quality products.

(c) The higher income groups spread widely and are limited in number.

(d) Religion, social traditions and taboos have a great impact on the behavior of the buyers.

(e) Family size is relatively big and there will be more than one earner in a family.

(f) Agriculture is the primary occupation and very few will be on non-agricultural activities.

(g) Reference groups will have greater impact on buyer behavior.

(h) Multiple languages, varied exposures to media and varied media habits, poor infrastructural facilities such as transport, health, shelter and communication also effect buying behavior.

(i) Rural people buy mostly in fairs and exhibitions.

The above characteristics of the rural markets create many problems for the companies which want to expand their business. High initial expenditure for market development, high distribution cost due to inadequate infrastructural facilities, and the inability of the small retailers to carry stocks without adequate credit facility are the major problems experienced by some of the companies which have already entered the markets. Against this background an attempt is made to analyze the existing distribution system in the rural markets of India. There are six channels in operation at present in the rural markets:

1. Producer-Urban wholesaler-Urban retailer-Rural buyer.

2. Producer-Urban wholesaler-Urban retailer-Village merchant-Rural buyer.

3. Producer-Urban wholesaler-Urban retailer-Big village merchant-Rural buyer.

4. Producer-Urban retailer-Big village merchant-Village merchant-Rural buyer.

5. Producer-Urban wholesaler-Big village merchantvillage merchant-Rural buyer.

6. Producer-Urban wholesaler-Urban retailer-Big village merchant-Village merchant-Rural buyer.

The products from the producers located in urban areas are taking root through a number of urban wholesalers/ stockists. From the urban wholesalers/ stockists the products are being purchased by the urban retailers. The village merchants, as mentioned already, who form final link in the distribution channel will go to the urban retailers to purchase a wide variety of goods as per to requirements of the market to which he represents. In between the urban retailers and village merchants, there is another link namely, big village merchants/ stockists who are also called as semi-wholesalers. These merchants establish contacts with village merchants of nearby villages and supply the required quantities to them. They also offer credit facilities to the village merchants. In addition, they supply goods to the creamy layer of the village population and other directly.

The village merchants, generally establish relations with the urban retailers as well as big village merchants for their requirements. They use rickshaws, cycle rickshaws, auto rickshaws, buses, vans, cycles, mopeds, bullock carts, tongas, etc. depending upon the availability and requirements for the purpose of transportation of goods. The shops generally will be residence-cum-outlet type, small in structure and poor conditions of storage. Therefore, the village merchants will purchase small quantities and try to purchase a number of times. As a result the cost of distribution is heavy. The distribution costs add to the price of the product and as such the rural buyer is charged heavily. A market research by Indian Market Research Bureau (IMRB) revealed that the small village retailer finds it difficult to lock up his capital in huge purchase of consumer items. All items of daily use were stocked by only the retailer. The retailer prefers to spread his capital into various items that are fast moving. $\mathrm{He}$ is interested in carrying stocks for a week only. He uses his own bicycle which also limits the physical carriage of goods.

The existing distribution system is not suitable to companies that want to gain something in the rural markets. The companies neither establish and maintain relations with all the merchants nor exercise control over them. The existing system leads to over dependency on the middleman to push goods to the markets. A longer channel 
is not cost effective as too many stops, storages, margins make the final price of the products very dear. An attempt is made therefore, to suggest a new distribution system that simplifies the flow of goods from producers to rural buyers. The suggested channel first of all, separates the urban channel and rural channel. The channel attaches a key role to the big village merchants/ stockists. The companies should identify the merchants in the big villages and make them authorized dealers/ stockists of their products. The village merchants in and around the big village should be selected and attached to the merchants in the big villages. This channel reduces the number of middlemen and also increases the accessibility to the village merchants. It also reduces the cost and delay in distributions, as there are only two middlemen in between the producer and the consumer.

As far as the physical distribution is concerned the best method is to operate company vans to a group of big village merchants (may be two or tree). The vans carry stocks from big village merchants to the village merchants so that the village merchants can have the stocks at their door-steps. The van also can collect the orders from the village merchants. It is not cost effective to operate independent vans by each company. The big village merchants should be motivated by the companies by offering liberal financial support to purchase vans for the purpose.

\section{Promotion}

Most buyers of rural India are basically illiterate; this factor is a major hurdle in the process of marketing communication. In addition to that, the economic backwardness, deep-rooted traditions and taboos, linguistic diversities and other cultural barriers contribute much to the problem. No single language, a simple illustration, theme or message can reach the widely varying rural buyers. The most important media to reach the rural market are radio and television. Cinema is also been considered as an effective medium of rural communication. The reach of radio is the highest, which covers 90 per cent of the rural population in the country. Until the emergence of television, radio alone played as a key mass communication media of rural India. Most marketing professionals agree that the market boom in the recent years has been triggered off by the most effective medium with the most reachable Doordarshan. In 1989 there were 178 lakh television sets in rural homes (133lakh black and white and 45 lakh colour), with a captive audience of 95 million which constitute 16 per cent of the nations entire population and 30 per cent of the estimated adult rural population. A senior marketing executive of a pharmaceutical company commented that what stopped marketers in the past was that there were no means of reaching the consumer. But with the explosion of $\mathrm{TV}$, that no longer holds good. It is not as if the rural market did not exist earlier. It always did. It's just that today, with the reach of TV into this market, we are seeing a jump in off take here too.
A mere extension of the promotional campaign designed for the urban markets will not yield fruitful result in the rural market. The medium should be different and the promotional campaign should take into consideration the medium habits, media reach and the behavior of the rural buyer. Point of purchase promotion tools, mobile audiovisual vans, music cassettes and records, and the traditional village shows can be used effectively for the purpose of communication. Group meetings, house to house campaign, demonstrations are also useful.

\section{CHANGING DIMENSIONS AND NEW LOOKS OF RURAL MARKETS}

By the end of the decade, according to latest NCAER income demographics report, there is going to be an explosion in the number of rich households. In households that earn over a crore rupees per annum or crorepatis - to use the most evocative term for this income category - the numbers rose four times between 1995-96 and 2001-02 and will grow seven times by the end of the decade, to 141,000 households. Any other category of rich households will grow five to six folds between 200102 and 2009-10. This change is not restricted to metros and towns. Nearly $12 \%$ of crorepatis are to be found in rural areas.

Table 1: The Number of Rich will continue to Explode

\begin{tabular}{|l|l|l|}
\hline Income Category & Rural Areas & Small Towns \\
\hline Under 90 & 110750 & 15400 \\
\hline $90-200$ & 20000 & 9060 \\
\hline $200-500$ & 3270 & 1575 \\
\hline $500-1000$ & 510 & 295 \\
\hline $1000-2000$ & 135 & 90 \\
\hline $2000-5000$ & 40 & 30 \\
\hline $5000-10000$ & 7 & 6 \\
\hline Over 10000 & 2 & 3 \\
\hline
\end{tabular}

The country's top 10 towns exhibited a growth of just 23 percent last year; growth in towns other than the top 60 was a much higher 36 percent. Indeed small towns have become so important that auto leader Maruti Udyog gets around a fifth of its total sales from these towns today - in 2000-2001, this was around an eighth. A tenth of the refrigerator market comes from towns that have five to ten lakh people and a fourth of car loans go to buyers in cities outside the top 20. And in the case of items like mopeds and motorcycles around half the total demand comes from rural areas, and is increasing over time. Indeed, in the case of refrigerators, the share of rural demand in the total doubled between 1985-86 and 2001-02. Since it is obvious that the lack of adequate electricity is the main reason for the relatively poor rural performance in this case, companies like Electrolux have even come up with an inverter-driven fridge called Bijlee that exclusively 
targets this market. What is important from the point of view of marketing bucks, of course, is not just the fact that rural areas and small towns have rich people but how concentrated they are on the ground. NCAER report says Haryana actually has more rich people in rural areas than it has in urban. Haryana state has 340 crorepati households in urban areas; it has 482 in rural areas. Punjab has 726 urban crorepatis as compared to 501 rural ones, and around 30,000 urban rich as compared to 28,000 rural rich. What is interesting about Haryana's density of crorepatis is that it is higher that that for rich cities like Kolkata. Kolkata has just 180 crorepati households per million as compared to rural Haryana's 199.

Table 2: Rural Demand is Key to Several Industries' Growth

\begin{tabular}{|l|l|l|l|l|}
\hline Year & $\mathbf{1 9 8 5 - 8 6}$ & $\mathbf{1 9 9 2 - 9 3}$ & $\mathbf{1 9 9 7 - 9 8}$ & $\mathbf{2 0 0 1 - 0 2}$ \\
\hline Mopeds & 42.0 & 39.6 & 46.7 & 48.4 \\
\hline Motorcycles & 52.0 & 47.7 & 51.0 & 52.9 \\
\hline Scooters & 36.0 & 27.8 & 34.5 & 40.1 \\
\hline Refrigerators & 14.0 & 18.1 & 26.3 & 28.0 \\
\hline Colour TVs & 11.0 & 31.1 & 34.7 & 36.0 \\
\hline $\begin{array}{l}\text { Washing } \\
\text { Machines }\end{array}$ & 12.0 & 9.9 & 15.3 & 14.9 \\
\hline
\end{tabular}

(Market share of rural areas in percent)

Source: NCAER, forthcoming study

For the country's marketers, this could mean a paradigm shift. We always knew much of India lives in its villages. But now we know that a significant number of its rich households also live here. There's a huge market for more expensive products that is still not been tapped fully.

\section{CONCLUSION}

Marketing in the rural India is beset with several problems. The greater market potentiality is really motivating the corporate worlds to break some of the problems to build a good marketing world. Already the companies like HLL, Dabur, Brook Bond, Lipton, Ponds, Bajaj, Enfield, Hero Cycles etc., which had the vision and foresight to identify the rural market early have been entirely successful. Other companies, which recognize the potential, are going ahead with their plans by heavy developmental expenditure. The requirement of the huge development expenditure stands on the way to many more companies that are enthusiastic to expand their business to rural areas. Marketing is a process of development; promotion of marketing activities creates greater facilities, employment, choice; and a good standard of living to the people. The government should realize the opportunities for the development of the rural areas. The corporate world should be given a helping hand by creating necessary infrastructure facilities. It is unfortunate that very little information is available relating to the rural markets to marketing professionals. There is a need for qualitative market research and for studies that may help understand the rural buyer or consumer.

\section{REFERENCES}

[1] Anurudra Bhanot, Far from the Madding Crowd', Financial Express, New Delhi, September, 1993 Advertising and Marketing: A Rural Boom' (ORG Survey), New Delhi, June,1990, p. 15.

[2] Mithilesh Jha, 'Rural Marketing: Some Conceptual Issues' Economic and Political Weekly, Bombay, Feb. 29, 1988.

[3] Geeta Manian, Marketing the Rural Rush, Business World, Bombay, 13th Feb.1991, p. 25.

[4] NCAER, Study Reports, 2001, 2002, 2004 